\title{
Sistem Pengambilan Keputusan Penentuan Pemasok Obat Pada Apotek Al Fayadh Farma Yogyakarta dengan Metode Topsis
}

\author{
Eka Bagus Saputro a,1, Anna Hendri Soleliza Jones a,2,* \\ a Program Studi Teknik Informatika, Universitas Ahmad Dahlan \\ 1ekabagussa12@gmail.com*; ${ }^{2}$ annahendri@tif.uad.ac.id; \\ * Penulis Korespondensi
}

Abstrak

Apotek merupakan tempat yang dapat digunakan untuk menyalurkan dan memberikan informasi obat yang lengkap kepada masyarakat. Kendala dapat terjadi dalam penyediaan obat di apotek, seperti dalam memilih pemasok obat yang mampu memberikan pelayanan terbaik bagi apotek dari segi harga maupun jasa. Sehingga kinerja dari apotek dalam pemesanan obat ke pemasok obat masih belum efisien. Oleh karena itu, sangat diperlukan sistem pengambilan keputusan penentuan pemasok obat di apotek Al Fayadh Farma Yogyakarta dengan metode TOPSIS agar kinerja apotek lebih efisisen.

Sistem pengambilan keputusan penentuan pemasok obat ini memerlukan 20 data pemasok dan 100 data obat yang didapatkan pada saat wawancara yang akan dimasukan ke dalam perhitungan metode TOPSIS dengan kriteria nilai harga pemasok, nilai stok barang, nilai layanan pengiriman, dan nilai sistem pembayaran sesuai proses bisnis yang telat dibuat. Sistem dirancang sesuai dengan permintaan dari apotek dan terakhir pengujian sistem tersebut diuji berdasarkan tampilan dan hasil akhir oleh pemilik apotek.

Hasil dari penelitian yang dilakukan adalah sistem pengambilan keputusan dengan metode TOPSIS dapat merekomendasikan pemasok obat dengan ketentuan kriteria yang diinginkan dengan meranking atau merekomendasikan 5 pemasok obat teratas sesuai dengan kriteria masing masing dari pemasok obat tersebut. Dengan pengujian akurasi didapatkan sebesar $80 \%$.

Kata Kunci: Apotek, TOPSIS, PBF (pedagang besar farmasi), Sistem Pengambilan Keputusan.

\section{Pendahuluan}

\subsection{Latar Belakang}

Menurut (Kepmenkes RI) No. 1332/MENKES/SK/X/2002, Apotek adalah suatu tempat dilakukannya pekerjaan kefarmasian penyaluran perbekalan farmasi kepada masyarakat. Yang dimaksud pekerjaan kefarmasian diantaranya pengadaan obat penyimpanan obat, pembuatan sediaan obat, peracikan, penyaluran dan penyerahan perbekalan farmasi serta memberikan informasi kepada masyarakat mengenai perbekalan kefarmasian yang terdiri dari obat, bahan obat, obat tradisional dan alat kesehatan. Apotek Al Fayadh Farma disetiap persediaan obat habis akan dilakukan pemesanan obat oleh apotek ke PBF(Pedagang Besar Farmasi). [1]

Pemesanan obat merupakan tanggung jawab pemilik apotek Al Fayadh Farma. Pemesanan dilakukan dengan memuat nama pemasok, nama obat, jumlah obat, harga, total harga, stok barang, layanan pengiriman, dan sistem pembayaran. Pemesanan obat ke PBF di apotek Al Fayadh Farma masih secara manual dalam prosesnya. Apotek memesan obat ke PBF dengan ketentuan kriteriakriteria, dimana proses penentuan pemasok obat masih dilakukan dengan cara manual yaitu mencatat dan membeli obat. Pada saat penentuan pemasok asisten apoteker yang bertugas memasok obat harus 
meminta persetujuan terlebih dahulu ke pemilik apotek yang akan memakan waktu lebih lama, Sehingga pemesanan obat tersebut tidak efisien dan lama. Untuk memudahkan dan mempercepat waktu maka diperlukan sistem pengambilan keputusan pemesanan obat.

Sistem pengambilan keputusan penentuan pemasok obat ini Dalam pengambilan keputusan tersebut pemilik apotek melihat data obat apakah obat tersebut habis atau tidak, jika obat habis maka asisten apoteker yang bertugas untuk memesan obat ke PBF akan melihat data pemasok dan merangking pemasok obat yang direkomendasikan oleh sistem pengambilan keputusan penentuan pemasok obat. Ada beberapa metode yang sering digunakan dalam perangkingan di dunia kesehatan seperti SAW(Simple Additive Weighting) dan AHP(Analytic Hierarchy Process). Metode Simple Additive Weighting $(S A W)$ sering juga dikenal istilah metode penjumlahan terbobot. Konsep dasar metode SAW adalah mencari penjumlahan terbobot dari rating kinerja pada setiap alternatif pada semua atribut. Analytic Hierarchy Process(AHP) merupakan salah satu teknik dalam pengambilan keputusan. Dalam mengambil keputusan, kriteria sebagai dasar penilaian, dan akan dihadapkan dengan lebih dari satu alternatif pilihan, sedangkan Sistem tersebut dalam meranking rekomendasi pemasok obat menggunakan metode TOPSIS, dimana metode tersebut melakukan perangkingan terhadap alternatif terpilih, dimana alternatif terpilih yang terbaik tidak hanya memiliki jarak terpendek dari solusi ideal positif, tetapi juga memiliki jarak terpanjang dari solusi ideal negatif. Perhitungan selesai akan muncul rekomendasi pemasok obat dari no 1 (pemasok obat dengan nilai terbanyak) sampai no 5 (pemasok obat dengan nilai terkecil). rekomendasi akan muncul, maka apotek akan memilih pemasok tersebut sesuai dengan rekomendasi sistem dan keinginan dari apotek yang sesuai dengan nilai kriteria yang ditentukan oleh apotek Al Fayadh Farma.

Sistem pengambilan keputusan belum pernah dipakai untuk masalah kesehatan khususnya dibagian apotek untuk memilih pemasok terbaik yang sesuai keinginan apotek tersebut, dikarenakan dalam pemilihan pemasok perlu adanya rumus perangkingan, itulah mengapa dipilihnya metode TOPSIS, karena memiliki konsep sederhana dan mudah dipahami, komputasinya efisien dan memiliki kemampuan untuk mengukur kinerja relatif dari alternatif-alternatif keputusan. Sistem pengambilan keputusan penentuan pemasok obat ini dibuat untuk membantu apotek Al Fayadh Farma untuk menentukan pemasok obat yang sesuai dengan kriteria yang diinginkan oleh apotek dengan cepat dan akurat tanpa melihat dan memilih dengan cara manual dan untuk meminimalisir waktu jika apotek kehabisan obat, maka sistem dengan cepat merekomendasikan pemasok obat mana yang akan dipilih untuk memasok obat tersebut.

\subsection{Identifikasi Masalah}

Berdasarkan latar belakang masalah maka dapat diidentifikasi permasalahan sebagai berikut :

1. Apotek masih memiliki kendala dalam menentukan pemasok obat ke PBF yang sesuai dengan kriteria apotek.

2. Penentuan pemasok obat di apotek Al Fayadh Farma Yogyakarta masih menggunakan cara manual dalam mencatat dan membeli obat ke PBF(pedagang besar farmasi).

\subsection{Batasan Masalah}

Batasan masalah pada penelitian ini adalah Sistem pengambilan keputusan yang dibangun dapat melakukan penentuan pemasok obat menggunakan metode TOPSIS.

\subsection{Rumusan Masalah}

Berdasarkan uraian latar belakang dan batasan masalah, maka didapatkan rumusan masalah, yaitu

1 Bagaimana membuat sebuah sistem Pengambilan Keputusan penentuan pemasok obat dengan metode TOPSIS pada apotek Al Fayadh Farma Yogyakarta.

2 Bagaimana pengujian sistem Pengambilan Keputusan penentuan pemasok obat dengan metode TOPSIS pada apotek Al Fayadh Farma Yogyakarta. 


\subsection{Tujuan Penelitian}

Penelitian ini bertujuan untuk mengembangkan sistem pengambilan keputusan penentuan pemasok obat pada apotek Al Fayadh Farma Yogyakarta dengan metode TOPSIS dan menguji sistem pengambilan keputusan yang sudah dibuat.

\subsection{Manfaat penelitian}

Manfaat yang dapat diperoleh dari penelitian ini adalah dengan adanya pembuatan sistem Pengambilan Keputusan penentuan pemasok obat ini diharapkan apotek Al Fayadh Farma Yogyakarta dapat menentukan pemasok obat ke PBF dengan mudah dan cepat.

\section{Kajian Pustaka}

\subsection{Kajian Penelitian Terdahulu}

Penelitian ini tidak terlepas dari penelitian-penelitian terdahulu yang telah dilaksanakan. Penelitian oleh Roichatul Jannah, Dedy Kurniadi, dan Muhammad Qomaruddin membahas tentang Penerapan Metode Technique For Order Preference By Similarity to Ideal Solution (Topsis) untuk Menentukan Prioritas Dokter Gigi Muda Bagi Pasien Pada Rumah Sakit Islam Gigi dan Mulut Sultan Agung, menyimpulkan bahwa Metode TOPSIS dapat diterapkan dalam sistem sebagai penentuan prioritas dokter gigi muda bagi pasien. Sistem yang telah dibangun dapat menjadi media rekomendasi para dokter gigi muda dalam mendapatkan pasien yang sesuai dengan profil yang sedang dibutuhkan. Hasil dari sistem yang dibuat berupa peringkat alternatif mulai dari yang paling baik hingga yang paling buruk. Pengujian sistem yang dilakukan dengan mencocokan hasil dari sistem dengan hasil prioritas user, berdasarkan pengujian sebanyak 3 kali maka diperoleh akurasi sebesar 80.94\%.[2].

\subsection{Landasan Teori}

\section{Sistem pendukung keputusan}

Sistem pendukung keputusan atau Decision Support Sistem (DSS) merupakan sistem informasi interaktif yang menyediakan informasi, pemodelan, dan pemanipulasian data. Sistem digunakan untuk membantu pengambilan keputusan dalam situasi yang semiterstruktur dan situasi yang tidak tersetruktur, dimana tak seorang pun tahu secara pasti bagaimana keputusan seharusnya dibuat. Sistem pendukung keputusan adalah sistem berbasis computer yang membantu para pengambil keputusan mengatasi berbagai masalah melalui interaksi langsung dengan sejumlah database dan perangkat lunak analitik. Tujuan dari sistem adalah untuk menyimpan data dan mengubahnya ke informasi yang terorganisir yang dapat diakses dengan mudah, sehingga keputusan-keputusan yang diambil dapat dilakukan dengan cepat, akurat, dan murah[3]. Membuat Sistem Pendukung Keputusan kita meggunakan metode algoritma pendukung keputusan. Adapun macam-macam metode algoritma yang digunakan dalam Sistem Pendukung Keputusan adalah sebagai berikut :

1. Metode Simple Additive Weighting $(S A W)$ sering juga dikenal istilah metode penjumlahan terbobot. Konsep dasar metode SAW adalah mencari penjumlahan terbobot dari rating kinerja pada setiap alternatif pada semua atribut (Fishburn, 1967) (MacCrimmon, 1968).

2. AHP (Analytic Hierarchy Process) merupakan salah satu teknik dalam pengambilan keputusan. Dalam mengambil keputusan, kita mempunyai kriteria sebagai dasar penilaian, dan kita juga akan dihadapkan dengan lebih dari satu alternative pilihan.

3. Weigthted Product adalah metode penyelesaian dengan menggunakan perkalian untuk menghubungkan rating atribut, dimana rating harus dipangkatkan terlebih dahulu dengan bobot atribut yang bersangkutan. Proses ini sama halnya dengan proses normalisasi

4. Metode TOPSIS adalah salah satu metode pengambilan keputusan multikriteria yang pertama kali diperkenalkan oleh Yoon dan Hwang pada tahun 1981. Metode ini merupakan salah satu metode yang banyak digunakan untuk menyelesaikan pengambilan keputusan secara praktis, Sehingga penulis memilih metode TOPSIS dikarenakan memiliki konsep sederhana dan mudah dipahami, komputasinya efisien dan memiliki kemampuan untuk mengukur kinerja relatif dari alternatif-alternatif keputusan. Semakin banyaknya faktor yang harus dipertimbangkan dalam proses pengambilan keputusan, maka semakin relatif sulit 
juga untuk mengambil keputusan terhadap suatu permasalahan. Apalagi jika upaya pengambilan keputusan dari suatu permasalahan tertentu, selain mempertimbangkan berbagai faktor/kriteria yang beragam, juga melibatkan beberapa orang pengambil keputusan. Permasalahan yang demikian dikenal dengan permasalahan multiple criteria decision making (MCDM). Dengan kata lain, MCDM juga dapat disebut sebagai suatu pengambilan keputusan untuk memilih alternatif terbaik dari sejumlah alternatif berdasarkan beberapa kriteria tertentu[4].

\section{Karakteristik}

Karakteristik dari DSS adalah sebagai berikut.[3]

1. Masalah semi terstruktur dan tidak terstruktur

2. Keputusan yang saling tergantung atau sekuensial

3. Mendukung inteligensi, desain, pilihan, implementasi

4. Mendukung berbagai proses dan gaya keputusan

5. Dapat diadaptasi dan fleksibel

\section{Komponen sistem pendukung keputusan}

Aplikasi sistem pendukung keputusan dapat terdiri dari subsistem seperti:

1. Manajemen Data memasukkan satu database yang berisi data yang relevan untuk situasi dan dikelola oleh perangkat lunak yang disebut sistem manajemen database (DBMS)

2. Manajemen Model merupakan paket perangkat lunak yang memasukkan model keuangan, statistik, ilmu manajemen, atau model kuantitatif lainnya yang memberikan kapasitas analitik dan manajemen perangkat lunak yang tepat. Perangkat lunak ini sering disebut sistem manajemen basis model (MBMS)

3. Antarmuka pengguna berkomunikasi dengan dan memerintahkan DSS melalui subsistem ini. Pengguna adalah bagian yang dipertimbangkan dari sistem. Para peneliti menegaskan bahwa beberapa kontribusi unik dari DSS berasal dari interaksi yang intensif antara komputer dan pembuat keputusan [3].

\section{Apotek}

Menurut (Kepmenkes RI) No. 1332/MENKES/SK/X/2002, Apotek adalah suatu tempat dilakukannya pekerjaan kefarmasian penyaluran perbekalan farmasi kepada masyarakat. Yang di maksud pekerjaan kefarmasian diantaranya pengadaan obat penyimpanan obat, pembuatan sediaan obat, peracikan, penyaluran dan penyerahan perbekalan farmasi serta memberikan informasi kepada masyarakat mengenai perbekalan kefarmasian yang terdiri dari obat, bahan obat, obat tradisional, alat kesehatan dan kosmetik. Tidak hanya menjalankan pekerjaan kefarmasian tetapi tugas pokok dan fungsi apotek juga harus dijalankan dengan sebaik-baiknya sesuai dengan standard prosedur yang telah ditetapkan.

\section{Obat}

Obat adalah bahan atau paduan bahan yang digunakan untuk mempengaruhi atau menyelidiki sistem fisiologi atau keadaan patologi dalam rangka penetapan diagnosa, pencegahan penyakit, penyembuhan penyakit, pemulihan, dan peningkatan kesehatan termasuk kontrasepsi dan sediaan biologis [5].

\section{Technique For Orders Reference by Similarity to Ideal Solution(TOPSIS)}

Technique For Orders Reference by Similarity to Ideal Solution atau TOPSIS dikenalkan pertamakali oleh Yoon dan Hwang pada tahun 1981 untuk digunakan sebagai salah satu metode dalam memecahkan masalah multikriteria.[6] Metode TOPSIS mampu melakukan perangkingan terhadap alternatif terpilih. Dimana alternatif terpilih yang terbaik tidak hanya memiliki jarak terpendek dari solusi ideal positif, tetapi juga memiliki jarak terpanjang dari solusi ideal negatif. Solusi ideal positif diartikan solusi yang memaksimalkan atribut keuntungan (profit) dan meminimalkan atribut biaya (cost), sedangkan solusi ideal negatif diartikan dengan solusi yang 
meminimalkan atribut keuntungan(profit) dan memaksimalkan biaya (cost). Secara umum, prosedur TOPSIS mengikuti langkah-langkah[7]:

1. Membuat matriks keputusan yang ternormalisasi.

2. Membuat matriks keputusan yang ternormalisasi terbobot.

3. Menentukan matriks solusi ideal positif dan matriks solusi ideal negatif.

4. Menentukan jarak antara nilai setiap alternatif dengan matriks solusi ideal positif dan matriks solusi ideal negatif.

5. Menentukan nilai preferensi untuk setiap alternative.

\section{Metode Penelitian}

\subsection{Objek Penelitian}

Objek penelitian adalah 20 data pemasok dan 100 data obat serta alur dari sistem pemesanan obat apotek Al Fayadh Farma Yogyakarta dengan metode TOPSIS untuk penentuan pemasok obat ke PBF.

\subsection{Deskripsi Metode Penelitian}

Penelitian ini menggunakan Metode TOPSIS. Metode TOPSIS digunakan untuk membantu sistem dalam memilih pemasok obat sesuai dengan kriteria yang dimiliki apotek Al Fayadh Farma Yogyakarta yaitu $\mathrm{c} 1=$ stok barang, $\mathrm{c} 2=$ harga pemasok, $\mathrm{c} 3=$ layanan pengiriman, dan $\mathrm{c} 4=$ sistem pembayaran. Setelah itu akan dilakukan perangkingan sesuai dengan perhitungan metode TOPSIS untuk memilih salah satu pemasok terbaik. Oleh karena itu, sangat diperlukan sistem pengambilan keputusan pengelolaan persediaan obat di apotek Al Fayadh Farma Yogyakarta agar kinerja apotek lebih efisien dan akurat.

\subsection{Metode Pengumpulan Data}

Diperlukan data untuk menunjang keberhasilan penilitian ini, teknik yang digunakan dalam pengumpulan data adalah observasi, wawancara dan dokumentasi.

Observasi adalah informasi yang dibutuhkan untuk penelitian yaitu proses jual beli di apotek $\mathrm{Al}$ Fayadh Farma juga proses sistem yang dipakai saat penentuan pemasok ke PBF. Informasi yang didapat adalah proses bisnis apotek Al Fayadh.

Wawancara adalah suatu percakapan antara dua orang atau lebih yang dilakukan oleh pewawancara dan pemilik apotek Al Fayadh yaitu Alfian Syarifuddin, M.farm.,Apt.

Membahas tentang proses sistem penentuan pemasok ke PBF, dengan pertanyaan sebagai berikut:

1. Apakah kendala apotek saat ini?

2. Permasalahan apa yang biasa terjadi pada saat apotek melakukan penentuan pemasok obat?

3. Apakah apotek Al Fayadh Farma sudah memiliki sistem pemilihan pemasok?

Setelah melakukan percakapan, hasil dari wawancara tersebut adalah 20 data pemasok dan 100 data obat serta mengetahui masalah yang ada di apotek Al Fayadh yaitu pendataan dan pengelolaan persediaan obat, apotek masih kesulitan dalam hal memilih pemasok obat yang mampu memberikan pelayanan terbaik bagi apotek dari segi harga maupun jasa.

Dokumentasi merupakan catatan peristiwa yang sudah berlalu. Dokumen bisa berbentuk tulisan, gambar atau karya karya momumental dari seseorang. Untuk mengetahui data yang diuji pada sistem,penulis mengambil data dari apotek Al Fayadh Farma yaitu data obat serta pemasok.[8]

\subsection{Spefisikasi Kebutuhan}

Kebutuhan yang diperlukan dalam penelitian ini yaitu:

1. Perangkat keras (Hardware) 
Perangkat keras yang dibutuhkan dalam penelitian ini yaitu seperangkat komputer dengan spesifikasi minimal RAM 4 GB.

2. Perangkat lunak (Software)

Adapun beberapa perangkat lunak yang digunakan selama proses penelitian:
a. Visual Studio Code
b. Xampp

3. Database

\subsection{Manajemen model}

Berikut adalah penerapan langkah langkah TOPSIS:

1. Metode TOPSIS dimulai dengan membangun sebuah matriks keputusan Matriks keputusan $\mathrm{X}$ mengacu terhadap $\mathrm{m}$ alternative yang akan dievaluasi berdasarkan kriteria.

$$
X=\left\{\begin{array}{cccc}
\mathrm{A} 1 & \mathrm{X} 11 \mathrm{X} 12 \mathrm{X} 13 & \ldots . \mathrm{X} 1 \mathrm{n} \\
\mathrm{A} 2 & \mathrm{X} 21 \mathrm{X} 22 \mathrm{X} 23 & \ldots . \mathrm{X} 2 \mathrm{n} \\
\mathrm{A} 3 & \mathrm{X} 31 \mathrm{X} 32 \mathrm{X} 33 & \ldots . \mathrm{X} 3 \mathrm{n} \\
A m & \mathrm{Xm} 1 \mathrm{X} m 2 X m 3 & \ldots . \mathrm{Xmn}
\end{array}\right\} \text { (1) }
$$

Ai $(\mathrm{i}=1,2,3, \ldots \mathrm{m})$ adalah alternative yang mungkin, $\mathrm{Xj}(\mathrm{j}=1,2,3, \ldots \mathrm{n})$ adalah atribut dimana performansi alternative diukur, Xij adalah performansi alternative Ai dengan acuan atribut $\mathrm{Xj}$.

2. TOPSIS membutuhkan rating kerja setiap alternatif Ai pada setiap kriteria $\mathrm{Cj}$ yang ternormalisasi :

$$
\begin{gathered}
r i j=\frac{X i j}{\sqrt{\sum_{i=1}^{m} x^{2} i j}}(2) \\
\text { dengan } i=1,2, \ldots, \mathrm{m} \text { dan } j=1,2, \ldots, n \\
\text { Dimana : rij = matrik ternormalisasi [i][j] }
\end{gathered}
$$

$\mathrm{Xij}=$ matrik keputusan $[\mathrm{i}][\mathrm{j}]$

3. Solusi ideal positif A+ dan solusi ideal negatif A-dapat ditentukan berdasarkan rating bobot ternormalisasi (yij) :

$v i j=$ wirij (3)

dengan $i=1,2, \ldots, m$; dan $j=1,2, \ldots, n$;

Dimana $:$ Vij = Elemen dari matriks keputusan yng ternormalisasi terbobot $\mathrm{V}$, wi $=$ Bobot dari criteria ke-j, rij = Elemen matriks keputusan yang ternormalisasi $\mathrm{R}$.

Dimana :

$$
\begin{aligned}
& A+=(y 1+, y 2+, \ldots, y n+) ; \\
& A-(y 1-, y 2-, \ldots, y n-) ; \quad(4)
\end{aligned}
$$

- $V j+=\max Y i j$ jika $\mathrm{j}$ adalah atribut Keuntungan.

- Min Yij jika j adalah atribut biaya.

- $V j-=$ min yij, jika $\mathrm{j}$ adalah atribut keuntungan. solusi ideal positif.

- max yij, jika $\mathrm{j}$ adalah atribut biaya Menentukan jarak antara alternatif Ai dengan

4. Jarak antara nilai setiap alternatif dengan matriks solusi ideal positif dan matriks solusi ideal negative :

$$
\begin{aligned}
& \mathrm{D} i+= \sqrt{\sum_{i-1}^{n}\left(V i^{+}-V i j\right)^{2}} \\
& \mathrm{D} i-=\sqrt{\sum_{i-1}^{n}\left(V i j-V i^{-}\right)^{2}}
\end{aligned}
$$


Dimana :

$D i+=$ Jarak alternative Ai dengan solusi ideal positif

$\mathrm{Vi}+=$ Solusi ideal positif [i]

$D i^{-}=$Jarak alternative Ai dengan solusi ideal negatif $Y$

$\mathrm{Vi}-=$ Solusi ideal negatif $[\mathrm{i}]$

$\mathrm{Vij}=$ matriks normalisasi $[\mathrm{i}][\mathrm{j}]$

5. Nilai preferensi untuk setiap alternative (Vi) diberikan sebagai :

$$
\mathrm{Vi}=\frac{D i^{-}}{D i^{-}+D i^{+}}
$$

dimana :

$\mathrm{Vi}=$ kedekatan tiap alternatif terhadap solusi ideal

$\mathrm{Di}+=$ jarak alternatif Ai dengan solusi ideal positif

Di- = jarak alternatif Ai dengan solusi ideal negatif

Nilai Vi yang lebih besar menunjukkan bahwa alternative Ai lebih dipilih.

\section{Hasil Dan Pembahasan}

\subsection{Hasil Pengumpulan Data}

Data yang digunakan dalam penelitian "Sistem Pengambilan Keputusan Penentuan Pemasok Obat pada Apotek Al Fayadh YOGYAKARTA dengan Metode Topsis" adalah 100 data obat apotek Al Fayadh dan 20 data pemasok yang didapatkan melalui metode wawancara ke apotek Al Fayadh YOGYAKARTA.

\subsection{Analisis Sistem}

\section{Kebutuhan fungsional}

Proses yang harus disediakan sistem sebagai berikut :

a. Sistem dapat menampilkan data login admin

b. Sistem dapat menampilkan data obat

c. Sistem dapat menampilkan data pemasok obat

d. Sistem dapat melakukan perangkingan pemasok obat

e. Sistem dapat menampilkan hasil perangkingan pemasok obat

\section{Kebutuhan non fungsional}

Properti yang dimiliki sistem :

a. Sistem dapat dijalankan pada komputer dengan prosesor minimal core i3 dan sistem operasi minimal windows 7.

b. Pengguna tidak dapat login setelah 1 bulan dengan username dan password yang sama sebelumnya.

\subsection{Pengujian Sistem}

Tahap terakhir dalam pembangunan sistem adalah pengujian sistem. Pengujian sistem dilakukan setelah pembuatan sistem selesai dan dapat berfungsi dengan baik. Pengujian ini dilakukan dengan tiga metode, yaitu Black -Box Test dan System Usability Scale (SUS).

\subsection{Black Box Test}

Pengujian program dilakukan oleh pemilik apotek dan teknisi apotek yang akan menggunakan sistem ini, yaitu Alfian Syarifuddin, M.Farm.,Apt dan Triyadi, dengan cara menguji seluruh menu dan fasilitas program, dan mengamati keluaran (output) program. Jika keluaran program dan seluruh 
fasilitas program berjalan dan tidak terjadi kesalahan pada saat dioperasikan, data keluaran telah sesuai dengan yang diharapkan, maka program dianggap baik. Hasil uji sistem dapat dilihat dibawah ini:

1. Berdasarkan hasil didapat presentase penilaian terhadap sistem yaitu, Ya $=14 / 14 \times 100 \%=$ $100 \%$, Tidak $=0 / 0 \times 100 \%=0 \%$. dari hasil presentase tersebut dapat ditarik kesimpulan bahwa data dan informasi yang disampaikan sudah sesuai dengan sistem pengambilan keputusan menggunakan metode topsis dalam menentukan pemasok obat.

\subsection{System Usability Scale (SUS)}

Pengujian SUS dilakukan oleh pemilik apotek dan karyawan apotek al fayadh farma yogyakarta yang akan melakuakan pemilihan pemasok obat. Pengujian dilakukan dengan memberikan kesempatan kepada responden untuk mencoba aplikasi secara langsung, kemudian diberikan suatu kuisoner untuk memberikan penilaian terhadap kinerja dari aplikasi pemilihan pemasok obat. Daftar responden yang melakukan test dalam metode ini ditampilkan tampak seperti pada tabel 4.2 dibawah ini [9]:

Tabel 4. 1 Daftar responden

\begin{tabular}{|l|l|l|}
\hline NO & NAMA & JABATAN \\
\hline 1 & Alfian Syarifuddin, M.Farm.,Apt & Pemilik Apotek \\
\hline 2 & Agung Dwi Nugroho & Asisten Apoteker \\
\hline 3 & Triyadi & Tenaga Teknis Farmasi \\
\hline 4 & Arina Dwi Saputri & Asisten Apoteker \\
\hline
\end{tabular}

Hasil pengujian SUS dapat dilihat pada keterangan dibawah ini:

Berdasarkan hasil, dapat diperoleh presentasi penilaian terhadap sistem yaitu $(\mathrm{X}-1)+(5-$ Y)*2.5=SUS. [9]

Keterangan :

$\mathrm{X}=$ pertanyaan positif

$\mathrm{Y}=$ pertanyaan negative

dari hasil penilaian terhadap sistem tersebut adalah 76.3, maka dapat disimpulkan bahwa sistem layak dipergunakan untuk melakukan pemilihan pemasok obat di apotek al fayadh farma yogyakarta.

\section{Kesimpulan}

Berdasarkan hasil penelitian "Sistem pengambilan keputusan pemesanan persediaan obat pada apotek Al Fayadh Farma yogyakarta dengan metode TOPSIS" dapat ditarik kesimpulan sebagai berikut :

1 Hasil pengujian yang dilakukan dengan 4 kali percobaan, akurasi keluaran sistem dengan hasil hitungan manual sebesar $80 \%$.

2 Pemesanan pemasok obat dilakukan dengan perhitungan rekomendasi sesuai dengan kriteria yang diinginkan dari apotek dan apotek percaya $80 \%$ bahwa Sistem pengambilan keputusan pemesanan persediaan obat pada apotek al fayadh farma yogyakarta dengan metode TOPSIS berjalan sesuai keinginan apotek, sehingga sistem dapat diterima oleh pihak apotek al fayadh farma.

\section{Saran}

Sistem pengambilan keputusan pengelolaan persediaan obat di apotek al fayadh farma masih memiliki kekurangan yang harus diperbaiki sehingga diharapkan adanya pengembangan lebih lanjut. Saran yang dapat digunakan sebagai acuan untuk pengembangan selanjutnya adalah sistem ini hanya 
mampu merangking 5 pemasok dengan 4 kriteria. Sistem masih dapat dikembangkan dengan merangking lebih dari 5 pemasok dengan kriteria yang lebih banyak juga.

\section{Daftar Pustaka}

[1] F. SMK, "Pengertian Apotek," 2011. [Online]. Available: http://farmasismk.blogspot.com/2011/11/pengertian-apotek.html.

[2] R. Jannah, D. Kurniadi, and M. Qomaruddin, "Penerapan Metode Technique For Order Preference By Similarity to Ideal Solution ( Topsis ) untuk Menentukan Prioritas Dokter Gigi Muda Bagi Pasien Pada Rumah Sakit Islam Gigi dan Mulut Sultan Agung,” J. Elektro dan Inform. Unissula, vol. 3, no. 1, 2018.

[3] T. Turban, Efraim;Aronson, Lav E.;Peng Liang, "Decision Support Systems and Intelligent Systems," in Decision Support Systems and Intelligent Systems, 7 JILID 1., ANDI, 2019.

[4] T. Pratama, "METODE SISTEM PENDUKUNG KEPUTUSAN," 12 JUNI, 2014. [Online]. Available: http://teguhpratam4.blogspot.com/.

[5] M. Muhlis, Diktat Kuliah Farmasetika. Yogyakarta: FARUAD, 2015.

[6] M. Rendra, H. Roisdiansyah, A. W. Widodo, and N. Hidayat, "Sistem Pendukung Keputusan Untuk Pemilihan Penanaman Varietas Unggul Padi Menggunakan Metode AHP dan TOPSIS," vol. 1, no. 10, pp. 1058-1065, 2017.

[7] A. Mubarok, H. D. Suherman, Y. Ramdhani, and S. Topiq, "Sistem Pendukung Keputusan Kelayakan Pemberian Kredit Dengan Metode TOPSIS," vol. 6, no. 1, pp. 37-46, 2019.

[8] Sugiyono, Metode Penelitian Kuantitatif, Kualitatif dan R\&D. Bandung: Alfabeta, 2013.

[9] A. Bangor, T. Staff, P. Kortum, J. Miller, and T. Staff, "Determining What Individual SUS Scores Mean : Adding an Adjective Rating Scale," vol. 4, no. 3, pp. 114-123, 2009. 